\title{
Dynamika transferu, ruch przemieszczenia. Polska poezja w drodze do Hiszpanii
}

\author{
Dynamic of Transfer, Displacement in Motion. Polish Poetry on the Way to Spain
}

\begin{abstract}
Adam Zagajewski is an established figure within the Spanish literary system. He might be the most admired author amongst foreign poets. His oeuvre is a reference point for Spanish poets from various generations and representing diverse literary movements. This article explores the mechanisms, which allowed the Polish poet to claim a central position in the new system and analyses the background as well as the course of this particular literary transfer.
\end{abstract}

Keywords: contemporary Spanish poetry, translation and transfer, literary status, Adam Zagajewski

Streszczenie: Adam Zagajewski ma ugruntowaną pozycję w hiszpańskim systemie literackim. Być może jest on najbardziej cenionym twórcą spośród zagranicznych poetów. Jego twórczość stanowi przedmiot odniesienia hiszpańskich poetów, reprezentujących różne pokolenia i kierunki. Artykuł przedstawia mechanizmy, które umożliwiały polskiemu poecie zajęcie centralnej pozycji w nowym systemie, analizuje tło i przebieg tego specyficznego transferu literackiego.

Słowa kluczowe: współczesna poezja hiszpańska, tłumaczenie i transfer, pozycja literacka, Adam Zagajewski

\section{Poezja na rynku przekładów. Polska a Hiszpania}

Przekłady poezji zajmują specyficzną pozycję na rynku tłumaczeń literackich. Jest to nade wszystko pozycja inna od tej, jaką ma proza, zwłaszcza powieść. Powieści, także tłumaczone, stanowią trzon działalności literackiej każdego wydawnictwa, one mogą przynieść największe zyski. Rynek poetycki, jak wiadomo, 
jest o kilka razy mniejszy niż rynek powieści, wystarczy wejść do jakiejkolwiek księgarni, żeby o tym się przekonać. Tłumaczenia poezji stanowią ogólnie znikomą niszę sprzedaży i działalności wydawniczej. Niemniej jednak są rynki bardziej i mniej dynamiczne. W tym aspekcie można obserwować różnice między Hiszpanią a Polską.

Tylko przez ostatnie lata w Polsce pojawiają się w zadowalającej ilości nowe książki poetyckie w tłumaczeniu, przede wszystkim za sprawą festiwalów poetyckich (Poeta Wolności w Gdańsku i Festiwal Miłosza w Krakowie). Mimo wszystko daleko tu jeszcze do sytuacji w Hiszpanii, gdzie nieprzerwanie od 30 lat tłumaczenie poezji jest jednym z filarów samego rynku poetyckiego. Aż trzy główne wydawnictwa wydają rocznie kilkanaście tomików w tłumaczeniu (przed kryzysem w 2008 roku kilkadziesiąt tomików rocznie). Wydawnictwa polskie publikują natomiast o wiele więcej tomików autorów rodzimych niż wydawnictwa hiszpańskie.

Kolejna różnica: w Polsce częściej tłumaczy się i publikuje wybory wierszy danego autora niż pojedyncze książki poetyckie (choć sytuacja ta nieznacznie zmieniła się za sprawą festiwalów, które wiążą się często z wydaniem jednego tomiku zaproszonego lub nominowanego poety). Przyjęło się, że wybory wierszy powinny reprezentować różne tomiki danego twórcy, przedstawiając jego główne linie pisarskie. Tak postępuje się z różnych powodów, przede wszystkim rzadko kiedy trafia się okazja ponownego tłumaczenia i publikowania utworów tego samego poety, pochodzących jedynie z innego (niż dotąd tłumaczony) zbiorku (inaczej dzieje się w wypadku tłumaczeń prozy). Prawidłowość ta dotyczy nawet znanych i cenionych autorów, w tym poetów nagrodzonych literacką Nagrodą Nobla. Oto przykłady ograniczone jedynie do poetów ostatnio nagrodzonych. Można znaleźć w przekładzie polskim jeden tomik Dereka Walcotta, wydany, kiedy poeta miał przyjechać do Polski na Festiwal Miłosza $^{1}$, nie ma przełożonych tomików wierszy meksykańskiego poety Octavio Paza (który dostał nagrodę dwa lata przed Walcottem), natomiast dostępnych jest po polsku kilka tomików Seamusa Heaneya (wybory i osobne tomiki, ale nie wszystkie) i cała twórczość Tomasa Tranströmera, który częściowo przetłumaczony był już przed otrzymaniem nagrody. Nie skupiam się tu na powodach, dla których dwaj wskazani wyżej poeci spotkali się z bardziej intensywną recepcją translatorską, ale wystarczy napomknąć o roli Heaneya w popularyzowaniu polskiej poezji za granicą i o prestiżu, towarzyszącym całej twórczości szwedzkiego poety na długo, zanim stał się on laureatem Nagrody Nobla (oraz o żywych relacjach Polski i Szwecji). Jeśli, dla porównania, sprawdzimy, jakie dzieła tych samych autorów zostały przetłumaczone na rynku hiszpańskim, odkryjemy, że translacja objęła większość tomików Heaneya i Walcotta

1 D. Walcott, Mapa Nowego Świata. Wiersze wybrane, wybór, red. M. Heydel, tłum. S. Barańczak i in., Kraków 2008. 
(w tym dwa poematy tego ostatniego poety w całości, Omeros i Another Life), całą twórczość Tranströmera, a także... całą twórczość Wisławy Szymborskiej.

W Hiszpanii, mimo że spotyka się tam wybory wierszy jednego autora obcego, chętniej niż w Polsce stosuje się tłumaczenie konkretnego tomiku albo rozłożoną w czasie serię tłumaczeń i publikacji kilku tomików tego samego poety. Porównując oba rynki przekładu poetyckiego, należy również postawić pytanie: z jakich języków najczęściej tłumaczy się wiersze? W wypadku polskiej kultury literackiej odpowiedź nie jest zaskakująca i brzmi: tak jak w prozie angielski jest językiem, z którego tłumaczy się najwięcej. Liczba książek poetyckich przetłumaczonych $\mathrm{w}$ Polsce $\mathrm{z}$ języka angielskiego w porównaniu z liczbą książek przekładanych z innych języków jest przytłaczająca, zwłaszcza od momentu zmian politycznych i kulturowych. W tym wypadku istniała konkretna przyczyna. Trzeba było skontrować poprzednią tradycję, tę, która akurat przyczyniła się do renomy polskiej poezji w zachodnim świecie literackim, z Czesławem Miłoszem, Zbigniewem Herbertem na czele - sojusznikiem w tym działaniu miała być tradycja poetów amerykańskich. Paradoksalnie jeden z autorów, który najbardziej starał się, aby wprowadzić anglosaską poezję w polszczyznę, to właśnie Miłosz² ${ }^{2}$ Sytuacja hiszpańska jest nieco odmienna. Oczywiście angielski też plasuje się na pierwszym miejscu, ale niemało jest tomików poetyckich przetłumaczonych z innych języków - począwszy od języków należących do tej samej, romańskiej rodziny językowej, jak włoski lub francuski, poprzez języki skandynawskie lub byłej Jugosławii, aż do wielkiej tradycji niemieckiej, ciągle obecnej w poezji hiszpańskiej od czasów romantyzmu (skłonność czytelników i wydawnictw bardziej do niemieckiego niż do angielskiego romantyzmu). Na przykład w ciągu ostatnich lat przetłumaczono wszystkie wiersze duńskiego poety Henrika Nordbrandta ${ }^{3}$ i serbskiego poety Vasko Popy ${ }^{4}$, tomiki poetów piszących po niderlandzku, takich jak Cees Nooteboom ${ }^{5}$ albo Leonard Nolens $^{6}$, czy też, sięgając do innej tradycji literackiej, kilka tomików palestyńskiego poety Mahmuda Darwisza ${ }^{7}$ - by wymienić tylko parę nazwisk. W tym kontekście poezja krajów Europy Wschodniej, a wśród nich przede wszystkim poezja polska, od początku XXI wieku osiągała coraz mocniejszą pozycję.

2 Na ten temat zob. M. Heydel, Gorliwość ttumacza. Przektad poetycki w twórczości Czestawa Mitosza, Kraków 2013 (rozdział 6: Kontynenty, s. 147-171).

3 H. Nordbrandt, Nuestro amor es como Bizancio, tłum. F. Uriz, Barcelona 2003.

4 V. Popa, El cansancio ajeno (Poesía completa), tłum. D. Sužnjević, Madrid 2012.

5 C. Nooteboom, Luz por todas partes (Antología), tłum. F.G. de la Banda, Madrid 2013.

6 L. Nolens, Puertas entreabiertas, 1 y 2, thum. S. van den Bremt, Madrid 2013.

7 M. Darwish, Menos rosas, tłum. M.L. Prieto, Madrid 2001; tenże, El lecho de una extraña, tłum. M.L. Prieto, Madrid 2005. 


\section{„Polska szkoła poezji”}

Każda literatura, nieznana w systemie literackim docelowym, aby była przyjęta w nowym języku i w nowych okolicznościach potrzebuje przynajmniej jednego elementu rozpoznawalnego. Czasem wystarczy przywołać tradycję literacką, jedno nazwisko lub recenzję zagraniczną. W świadomości hiszpańskiego czytelnika poezja skandynawska osiągnęła mocną pozycję dzięki pracy tłumacza Francisca J. Uriza i dzięki antologii, którą on sam układał. W wypadku polskiej poezji istnieje kilka czynników, które zbiegły się pod koniec XX wieku i w pierwszej dekadzie XXI wieku i które spowodowały, że poezja ta zaczęła coraz mocniej oddziaływać na czytelników i poetów hiszpańskich. Wśród tych czynników bodaj pierwszymi, najbardziej decydującymi okazały się pozycja poezji polskiej w krajach anglosaskich i idea „polskiej szkoły poezji” - być może jedno z najbardziej fortunnych określeń w dyskursie o poezji światowej drugiej połowie XX wieku. Warto przypomnieć pokrótce jego genezę.

Czesław Miłosz w swojej znanej antologii Polish Postwar Poetry ustala, daleko od geograficznego centrum swojego języka, kanon poezji polskiej drugiej połowy XX wieku, który będzie uznany za granicą i który rzutuje na stworzenie kanonu w samej Polsce, choć, jak wiadomo, nie w sposób natychmiasto$w y^{8}$. W miarę jak pojawiały się nowe wydania tej antologii, Miłosz dodawał do niej wiersze młodszych poetów. Jeden z nich, Adam Zagajewski, zamyka antologię, i z biegiem lat staje się najbardziej rozpoznawalną twarzą polskiej poezji poza swoim krajem. Najpierw w świecie anglosaskim, a potem w niektórych innych krajach. W przedmowie do antologii Czesław Miłosz przedstawiał kilka cech, które rzekomo wszyscy poeci mieli i podzielili i które potem miały stworzyć pojęcie „szkoły polskiej poezji”. Jedną z nich jest ironia, albo raczej specyficzne użycie ironii: „Its mixture of macabre an humorous elements, its preoccupation less with the ego than with the dramas of history, the relish with which it handles and remodels moral maxims did not appear all of a sudden in our time" ${ }^{\prime}$. Drugą, obok wspomnianej wyżej przedmowy, ważną wypowiedzią Miłosza, konstruującą wizerunek „polskiej szkoły poezji”, jest późniejsza o kilkanaście lat książka Świadectwo poezji. Sześć wyktadów o dotkliwościach naszego wieku, będąca zapisem cyklu wykładów wygłoszonych na katedrze Charles Eliot Norton w Harvardzie. Co ważne, publikacja ta została najpierw wydana $\mathrm{w}$ języku angielskim pod tytułem The Witness of Poetry ${ }^{10}$ (choć pierwotną wer-

8 C. Miłosz, Postwar Polish Poetry, wyd. 3 rozszerz., Berkeley-Los Angeles 1983. Pierwsze wydanie ukazało się w roku 1965, drugie w roku 1970. Jak można wywnioskować, recepcja tej antologii przebiegała w Hiszpanii z opóźnieniem.

9 Tamże, s. xii.

10 C. Miłosz, The Witness of Poetry, Cambridge 1994 (1983). 
sją, jak sam Miłosz informuje w przedmowie polskiego wydania, była wersja polska $\left.{ }^{11}\right)$. W wykładzie V, „Ruiny i poezja”, Miłosz twierdzi między innymi:

Do zastanawiających cech polskiej poezji ostatnich dekad należy poszukiwanie równowagi w warunkach chaosu i zupełnej płynności wszelkich wiar, co chyba ma dostatecznie ogólne znaczenie, żeby o tym tutaj mówićn ${ }^{12}$.

Sąd ten formułowany był w kontekście poetyki Mirona Białoszewskiego. W ten sposób Miłosz tworzył wizję polskiej poezji, utrwaloną potem w świecie innych zachodnich literackich tradycji. Parę stron później dodawał:

Jaka może być poezja w XX wieku? Wydaje mi się, że kiedy szukamy tej linii, za którą rozpościera się tylko strefa milczenia, natrafiamy na poezję polską. Nastąpiło w niej szczególne spotkanie jednostkowego z historycznym, co znaczy, że wydarzenia spadające na całą zbiorowość za odbierane przez poetę jako dotykające go w sposób najbardziej osobisty. Poezja wtedy nie jest alienowana, czyli, zgodnie $\mathrm{z}$ etymologią tego terminu, nie jest cudzoziemką w społeczeństwie ${ }^{13}$.

Tu kontekst jest trochę inny. Miłosz odnosi się do Herberta, przedstawia późną twórczość Aleksandra Wata, następnie zaś zaczyna małą diatrybę przeciw symbolizmowi i konsekwencjom tego ruchu w poezji.

Nie wspominam już o innych tekstach Czesława Miłosza, broniących tez o „polskiej szkole poezji”, takich chociażby jak $Z$ poezją polska przeciw światu ${ }^{14}$ czy Przeciw poezji niezrozumiatej ${ }^{15}$, dlatego że czytelnicy hiszpańscy nieznający języka polskiego nie mieli do nich dostępu. Dwa przywołane przeze mnie wystąpienia w języku angielskim mogły jednak oddziaływać. Mimo że polska poezja była przetłumaczona i wprowadzona w nurt hiszpańskiej tradycji stosunkowo późno, kilku poetów hiszpańskich odpowiedzialnych za zmianę estetyczną ostatnich lat znało pojęcie „polskiej szkoły poezji” i twórców, którzy uosabiali tę heterogeniczną grupę, z Miłoszem, Herbertem i Szymborską na czele ${ }^{16}$. Okazuje się to kluczowe dla zrozumienia roli polskich poetów w tra-

11 Tenże, Świadectwo poezji. Sześć wyktadów o dotkliwościach naszego wieku, Warszawa 1990 (1983), s. 6.

12 Tamże, s. 87.

13 Tamże, s. 93.

14 C. Miłosz, Życie na wyspach, Kraków 1997, s. 124-133.

15 Tamże, s. 94-107. Tekst ten wprawdzie nie mówi bezpośrednio o polskiej poezji, ale wyraża jej koncepcję, towarzyszącą autorowi od lat sześćdziesiątych. Esej miał się pojawiać w antologii poezji światowej Wypisy z ksiąg użytecznych, ale ostatecznie Miłosz poprzedził antologię innym tekstem, bardziej łagodnym w wymowie, także występującym w wersji angielskiej książki (zob. C. Miłosz, A Book of Luminous Things: An International Anthology of Poetry, Orlando 1998, s. xv-xx).

16 Jordi Doce, poeta należący do średniego pokolenia, pisał kilkakrotnie o Miłoszu, i zawsze wspomina, że odkrył go przez antologię Polish Postwar Poetry, jak również tłumaczenie 
dycji hiszpańskiej oraz wyboru autorów, którzy mają obecnie osobne tomiki w języku hiszpańskim.

\section{Polska poezja trafia do Hiszpanii: dynamika transferu, ruch przesunięcia}

Kiedy Czesław Miłosz dostaje Nagrodę Nobla, nie ma jeszcze ani jednego zbioru jego wierszy przetłumaczonego na język hiszpański. Dopiero w roku 1984 ukazuje się nieduży wybór w tłumaczeniu Barbary Stawickiej. Wybór bardzo osobisty, wiersze nie są pogrupowane według tomików ani nie są ułożone chronologicznie, co nasuwa różne przemyślenia o horyzoncie tłumacza ${ }^{17}$. To nie jest jeszcze moment na Miłosza poetę, wymieniony wybór zostaje w tamtych latach prawie niezauważony i czytelnicy hiszpańscy, którzy będą poznawać jego wiersze, raczej zrobią to w języku angielskim, co stwarza specyficzny obraz Miłoszowej poetyki.

Nieco wcześniej zostały przetłumaczone trzy prozatorskie książki Czesława Miłosza: Zniewolony umyst ${ }^{18}$ i Rodzinna Europa ${ }^{19}$ w 1981 roku oraz Dolina $I s s y^{20} \mathrm{w}$ roku 1982. Druga jest przetłumaczona z francuskiego, co zostaje wyraźnie zaznaczone na stronie redakcyjnej, natomiast brak tej informacji w wypadku Zniewolonego umystu, nie wiadomo dokładnie, z którego języka dokonana była translacja ${ }^{21}$. Tylko Dolina Issy została przetłumaczona bezpośrednio z polskiego. Ta sytuacja nasuwa pewien obraz sytuacji polskiej literatury przetłumaczonej na hiszpański. Mała znajomość języka polskiego, brak kontaktów od drugiej wojny światowej z powodów politycznych (Hiszpania dopiero co zaczęła żyć w nowym systemie demokratycznym na początku lat osiemdziesiątych), brak wcześniejszych tłumaczeń z wyjątkiem nielicznych przypadków - to wszystko spowodowało, że polscy autorzy byli prawie nieznani, nawet jeśli dostawali Nagrodę Nobla.

w czasopiśmie „Modern Poetry in Translation”, pod redakcją Teda Hughesa i Daniela Wiessbortha. Zob. J. Doce, Materialismo del creyente [w:] tenże, Zona de divagar, Madrid 2014, s. 74-87.

17 Pojęcie zdefiniowane przez Antoine’a Bermana jako: „'ensemble des paramètres langagiers, littéraires, culturels et historiques qui "déterminen« le sentir, l'agir et le penser d'un traducteur" (A. Berman, Pour une critique des traductions: John Donne, Paris 1994, s. 79. Cytuję tłumaczenie za Magdą Heydel: „zestaw językowych, literackich, kulturowych i historycznych parametrów, które »determinują" sposoby odczuwania, działania, i myślenia tłumacza". M. Heydel, dz. cyt., s. 99.

18 C. Miłosz, El pensamiento cautivo, tłum. E. Revol, Barcelona 1981.

19 Tenże, Otra Europa, tłum. A. Cousté, Barcelona 1981.

20 Tenże, El valle del Issa, tłum. A. Rodón Klemensiewicz, Barcelona 1982.

21 Pracując nad nowym hiszpańskim tłumaczeniem tego dzieła, miałem okazję bardziej szczegółowo przyjrzeć się tej pierwszej translacji. Stwierdziłem, że została ona zrobiona poprzez tłumaczenia angielskie i francuskie. 
Trzeba stale brać pod uwagę, że odnoszę się do literatury hiszpańskiej i sytuacji języka hiszpańskiego na Półwyspie Iberyjskim. Sytuacja była zupełnie inna w niektórych krajach Ameryki Łacińskiej, na przykład w Meksyku funkcjonowało czasopismo „Vuelta”, w którym naczelnym redaktorem był poeta Paz, wydające autorów z wielu różnych literatur. Natomiast w latach osiemdziesiątych w Hiszpanii mało się wiedziało o polskiej prozie, a tym mniej o polskiej poezji: hiszpańska poezja czy hiszpańscy poeci nie byli bardzo otwarci na wpływy z zewnątrz, a jeśli jakieś docierały, to raczej z wielkich literatur zachodnich. W ciągu kolejnych lat w hiszpańskiej kulturze poetyckiej zaszły jednak radykalne zmiany, które przygotowały grunt dla bardziej chłonnej i wielostronnej recepcji różnych zjawisk i nurtów poezji światowej.

Jednym z pierwszych zwiastunów przewrotu w poezji hiszpańskiej okazała się twórczość jednego z kluczowych poetów XX wieku, Jaime Gil de Biedmy, który kładł wyraźny nacisk na poetykę kilku autorów anglosaskich, z W.H. Audenem na czele, a z ich pomocą „otwieral” tradycję hiszpańską 22 . W latach osiemdziesiątych pojawiają się już nowe antologie ${ }^{23}$, próbujące klasyfikować nowe głosy i nowe tendencje poetyckie, określane różnymi nazwami, z których ostaną się pojęcia „poezja doświadczenia” oraz „poezja figuratywna”"24. Poeci tamtych lat odżegnują się od swoich poprzedników, od poezji pokolenia „novisimos”, której filarami były „wysokie” odniesienia kulturowe, egzotyzm i nawiązanie do symbolizmu (nazywanego w Hiszpanii modernizm, lecz mającego mało wspólnego z modernizmem anglosaskim). Nowe tendencje mają korzenie w poetyce „linii wyraźnej” (uosabianej przez twórczość poety Antonia Machado), opierają się na codzienności, wolą porównanie od metafory, a także eksploatują mono$\log$ dramatyczny (co wiązało się z inspiracją w postaci The Poetry of Experience, książką Roberta Langbauma ${ }^{25}$, odkrytą dla czytelnika hiszpańskiego przez de Biedmę). Po pierwszej fali zmian w poezji hiszpańskiej następuje druga, w latach dziewięćdziesiątych, która otworzyła w pełni wachlarz możliwości i trendów poetyckich. Powstają kolejne antologie, porządkujące nowe zjawiska ${ }^{26}$, wyrażające otwartość na różne dykcje poetyckie. Wśród członków tego nowego, bardzo eklektycznego, pokolenia znajdują się poeci dobrze zorientowani w zachodnim (czasem także we wschodnim) świecie poetyckim, część z nich jest zarazem tłumaczami. Dekada lat dziewięćdziesiątych stworzyła podwaliny nowej

22 J. Gil de Biedma, El pie de la letra: Ensayos 1955-1979, Barcelona 1980.

23 Inaczej niż w Polsce na rynku hiszpańskim prawie wcale nie ma czasopism publikujących wiersze. Istnieje natomiast popularna instytucja antologii, służąca organizowaniu życia literackiego.

24 Mówią o tym między innymi Miguel García-Posada, Luis Antonio de Villena i José Luís García Martín (zob. Bibliografia).

25 R. Langbaum, The Poetry of Experience: The Dramatic Monologue in Modern Literary Tradition, New York 1980 (1957).

26 Trzeba by wymienić antologie Juana Carlosa Abrila i Rafaela Moralesa Barby (zob. Bibliografia). 
sytuacji, w której własna tradycja odczytywana jest obok innych tradycji literackich lub innych głosów. Sytuacja ta inaczej warunkuje proces recepcji polskiej poezji. Kiedy Wisława Szymborska dostała Nagrodę Nobla w roku 1996, żaden jej wiersz nie był jeszcze przetłumaczony na język hiszpański. A jednak bardzo szybko, najpierw w gazetach, a potem w różnych czasopismach, pojawiły się tłumaczenia utworów noblistki, dokonywane bezpośrednio z oryginału lub z języka angielskiego. Po trzynastu latach od pierwszych przekładów wierszy Miłosza grunt literacki był zupełnie inny. Dwa lata przed Noblem dla Szymborskiej ukazał się pierwszy tomik Zbigniewa Herberta, przetłumaczony na język hiszpański: Raport z oblężonego Miasta $i$ inne wiersze $e^{27}$. Wydawca tomiku wyraźnie przedstawiał autora Pana Cogito jako żelaznego kandydata na Nobla ${ }^{28}$. Minęło parę lat, zanim Herbert pojawił się ponownie na rynku hiszpańskim, najpierw poprzez swoje eseje, a dopiero w roku 2012 poprzez wiersze zebrane ${ }^{29}$. W tym czasie kilka tomików polskiej poezji zawitało do Hiszpanii: przetłumaczono Tadeusza Różewicza ${ }^{30}$, Ewę Lipską ${ }^{31}$, Jerzego Lieber$\mathrm{ta}^{32}$ i Czesława Miłosza ponownie w dużym wyborze w roku $2011^{33}$, opublikowano antologię polskich poetów urodzonych między rokiem 1960 a $1980^{34}$. W tych też latach ukazują się kolejne tomiki Wisławy Szymborskiej ${ }^{35}$. Po roku 2012 opublikowano jeszcze tomiki innych polskich autorów, ale można powiedzieć, że to właśnie lata 1996-2012 były najpłodniejsze pod względem różnorodności tłumaczeń poetyckich (nie przypadkiem wszystko to nastąpiło przed kryzysem ekonomicznym, który dotknął bardzo dotkliwie struktury wydawnicze). Oprócz wspomnianej antologii młodszej twórczości poetyckiej wszystkie przekłady polskiej poezji na język hiszpański tego okresu reprezentują tradycyjnie pojmowaną „polską szkołę poezji” - prawie nie dochodzi do szukania innych tonów, innych głosów, które raczej nie są przychylnie traktowane przez hiszpańskie wydawnictwa.

27 Z. Herbert, Informe desde la ciudad sitiada y otros poemas, tłum. X. Ballester, Madrid 1993.

${ }_{28}$ To samo wydawnictwo, Hiperion, opublikowało też parę lat wcześniej wiersze szwedzkiego poety Tomasa Tranströmera, zaś w roku 1992 tomik North Seamusa Heaneya. Edycje te poprzedzały przyznanie obu poetom Nagrody Nobla. W przypadku Szymborskiej było to potem pierwsze wydawnictwo, które zajęło się publikacją jej wierszy. Wybór został przetłumaczony przez grupę tłumaczy skupionych wokół Instytutu Cervantesa w Warszawie, z którego wywodziła się para tłumaczy wszystkich wierszy Szymborskiej: Abel Murcia i Gerardo Beltran.

29 Z. Herbert, Poesía completa, tłum. X. Ballester, Barcelona 2012.

30 T. Różewicz, Poesía abierta, tłum. F. Presa González, Barcelona 2003.

31 E. Lipska, Fresas blancas, tłum. F. Presa González, Madrid 2001; taż, La astillal La naranja de Newton, tłum. A. Benítez Burraco, A. Sobieska, Gijón 2010.

32 J. Liebert, Antología poética, tłum. A. Benítez Burraco, A. Sobieska, Madrid 2005. Wybór akurat tego poety wśród innych przetłumaczonych poetów polskich może dziwić.

33 C. Miłosz, Tierra inalcanzable. Antología poética, tłum. X. Farré, Barcelona 2011.

34 A. Murcia, G. Beltrán, X. Farré, Poesía a contragolpe, Zaragoza 2012.

35 Niemniej jednak wiersze prawie zebrane były wydane w Meksyku, a nie w Hiszpanii. 
Wytwarzało się w ten sposób znamienne przesunięcie: w Hiszpanii nadal utrzymywał się i utwierdzał klasyczny obraz polskiej poezji, podczas gdy w Polsce poezja była już na innych torach, a nowsze pokolenia poetów uwalniały się od tego silnego wzorca i od tej wyobraźni poetyckiej, która wciąż traktowana była w innych krajach jako specyficznie polska. Sytuacja ta ma różne przyczyny, jedną z nich jest to, że poeci hiszpańscy, którzy dokonali zmiany estetycznej, szukali „dawnych” poetów polskich jako punktu odniesienia ${ }^{36}$; akurat przewrót dokonywany w ostatnich latach w polskiej poezji wydawał się ich mniej zaciekawiać. Lekkie opóźnienie względem innych krajów europejskich we wprowadzaniu polskich poetów XX wieku też spowodowało, że najbardziej obecni w przekładach byli twórcy drugiej połowy XX wieku, nie zaś z przełomu stulecia XX i XXI.

Problem wszystkich literatur, języków, które w pewnym momencie swojej historii utwierdziły swą markę, polega na tym, że trudno jest zrywać z tym obrazem na oczach zagranicznych odbiorców, przyzwyczajonych do konkretnej estetyki i oczekujących jej kontynuacji. Podobna sytuacja dotyczyła powieści autorów Ameryki Łacińskiej, gdzie boom na prozę realizmu magicznego już dawno minął i gdzie nowi autorzy piszą akurat przeciw temu nurtowi. Nagroda Nobla czasem wydaje się po latach utwierdzać dawne tendencje, jak w przypadku Vargasa Llosy albo też Szymborskiej, choć w wypadku literatur mniej znanych może również sprzyjać wprowadzeniu na obce tereny kulturowe autorów dalekich od laureata pod względem poetyki czy wizji świata.

\section{Ruchoma pozycja Adama Zagajewskiego}

W przypadku Adama Zagajewskiego wolno mówić o - opisywanym już w niniejszym numerze „Kontekstów Kultury” (zob. artykuł A. Kremer, s. 5-14) zjawisku „przesunięcia”, czy „przemieszczenia” pozycji autora w toku zagranicznej recepcji jego twórczości. Twórca Jechać do Lwowa staje się jednym z najbardziej cenionych i poczytnych poetów w języku hiszpańskim, a uwieńczeniem jego pozycji w hiszpańskim systemie literackim jest nagroda Princesa de Asturias de las Letras, przyznana w 2017 roku. Oczywiście nie można powiedzieć, że Adam Zagajewski nie zajmuje mocnej pozycji w literaturze polskiej, ale jednak poeta ten nie dostał żadnej ważnej nagrody w kraju swojego języka. I ogólnie jest mało ceniony wśród poetów średniego i młodszego pokolenia, co pokazuje słynny artykuł Jarosława Klejnockiego Dziesięć powodów, dla

36 Jednym z najbardziej ewidentnych przykładów takiego podejścia jest stosunek do polskiej poezji zawarty w eseistyce Jordiego Doce. Podobną fascynację ,polską szkołą poezji” wyrażał też przy różnych okazjach i w rozmaitych tekstach Martín López-Vega. 
których inni poeci polscy nienawidzq Adama Zagajewskiego ${ }^{37}$. Prawie nie można znaleźć autorów polskich młodszego i średniego pokolenia, którzy przyznaliby, że autor Ziemi ognistej jest dla nich jednym ze wzorów, albo że jego poetyka stanowi dla nich inspirację. Oczywiście można dostrzec elementy poetyki Adama Zagajewskiego u niektórych poetów, ale to nie jest ton najbardziej obecny. Mało kto odnosi się do podstawy i obrony wysokiego stylu, wyrażanej w eseju Uwagi o wysokim stylu ${ }^{38}$. Natomiast w Hiszpanii to właśnie Zagajewski jest poetą transpokoleniowym. W różnych wywiadach przy okazji recenzji każdego nowego tomiku tłumaczonego na hiszpański poeci z pokolenia „poezji figuratywnej” lub „poezji doświadczenia”, także poeci następnej generacji, teraz już średniej, a nawet jeszcze od nich młodsi - wymieniają Adama Zagajewskiego.

Aby zrozumieć wyjątkową pozycję tego akurat poety polskiego na tle hiszpańskiej poezji, trzeba też dostrzec znaczenie działań wydawniczych, a więc to, co - za koncepcją Antoine'a Bermana - moglibyśmy określić mianem horyzontu wydawniczego ${ }^{39}$. Inni autorzy tego samego co Zagajewski pokolenia ${ }^{40}$ albo nawet Różewicz nie mogli się cieszyć takim dobrym przyjęciem, byli publikowani przez wydawnictwa mniej znaczące, które miały ograniczony wpływ nawet w obrębie świata poetyckiego.

W bardzo krótkim czasie, w ciągu jednego roku 2004, pojawiło się najpierw hiszpańskie tłumaczenie książki W cudzym pięknie, następnie zaś, ledwie $^{41}$ parę miesięcy później, w innym wydawnictwie, ukazał się po hiszpańsku pierwszy tomik wierszy - Ziemia ognista ${ }^{42}$. Publikacja tego tomiku - i to w takiej formie - jest bardzo znacząca: spośród tłumaczeń na języki zachodnie tylko przekład hiszpański zachowuje oryginalny układ wierszy i tytuł. Tłumaczenia na inne języki - choć oczywiście wykonywane z oryginału polskiego - przejmowały układ tekstów ustalony w angielskiej translacji książki, odzwierciedlały także tytuł wersji angielskiej (Mysticism for Beginners); ewentualnie - łączyły wiersze z Ziemi ognistej z wierszami z innych tomików poety, tworząc w ten sposób rodzaj antologii. Wierne odtworzenie kompozycji Ziemi ognistej było wyraźną decyzją wydawcy, czyli oficyny Acantilado, zgodną z jej podstawową

37 J. Klejnockiego, Dziesięć powodów, dla których inni poeci polscy nienawidzq Adama Zagajewskiego [w:] i cień i światto... O twórczości Adama Zagajewskiego, red. A. Czabanowska-Wróbel, Kraków 2015, s. 79-92.

38 A. Zagajewski, Uwagi o wysokim stylu [w:] tegoż, Obrona żarliwości, Kraków 2002, s. $29-51$.

39 Parafrazuję w tym miejscu wprowadzone przez Bermana termin „horyzont tłumacza” (por. przyp. 17). Oprócz pojęcia „horyzontu tłumacza” teoretyk francuski wprowadza jeszcze kategorie „position traductive” (pozycja traduktologiczna) i „projet de traduction” (projekt przekładowy), por. A. Berman, dz. cyt., s. 74 i 76. Berman skupia się na działalności tłumacza, ale nie uwzględnia działalności wydawnictwa, która ewidentnie ma swoje cele i swój mocno zdefiniowany „horyzont” - stąd proponowany przeze mnie termin.

40 Oprócz tomów Lipskiej ukazał się po 2012 roku zbiór Stanisława Barańczaka.

41 A. Zagajewski, En la belleza ajena, tłum. Á.E. Díaz-Pintado Hilario, Valencia 2004.

42 Tenże, Tierra del fuego, tłum. X. Farré, Barcelona 2004. 
strategią, stosowaną od momentu wejścia na rynek poezji (wcześniej wydawca ten słynął z publikacji tłumaczeń prozy i esejów). W przeciwieństwie do innych wydawnictw w dziale poezji z katalogu Acantilado nie ma wyborów wierszy, lecz pełne tomiki. Od roku 2004 każda nowa książka Adama Zagajewskiego (esej, proza i poezja) ukazuje się, po niedługim czasie od polskiej premiery, w tymże wydawnictwie ${ }^{43}$. Projekt Acantilado zakłada opublikowanie w przekładzie hiszpańskim całej twórczości poety polskiego, który traktowany jest jako autor reprezentatywny dla wielkiej literatury środkowoeuropejskiej, i który we współczesnych czasach odnawia tę tradycję (podobnie jak Lászlo Krasznahorkai, Jurij Andruchowycz lub Andrzej Stasiuk w tym samym wydawnictwie). Do tej pory (prócz pionierskiej Ziemi ognistej) ukazały się następujące tomiki poetyckie Zagajewskiego: Pragnienie (2005) ${ }^{44}$, Anteny $(2007)^{45}$, Niewidzialna ręka $(2012)^{46}$, Asymetria (2017) ${ }^{47}$ i już jest zaplanowane tłumaczenie Prawdziwego $\dot{z y}$ cia. Obecnie nie ma bodajże żadnego innego żyjącego poety zagranicznego, który miałby aż tyle tomików przetłumaczonych na język hiszpański. Po polskiej poezji najbardziej intensywną recepcję ma w tym momencie poezja rumuńska, ale jak dotąd ukazało się jeszcze niewiele pozycji - prawie sama Ana Blandiana z trzema tomikami wierszy zajmuje całą przestrzeń poetyckich tłumaczeń z języka rumuńskiego.

Z jednej strony bardzo świadomy projekt wydawniczy, prestiż wydawnictwa, które w obecnej chwili jest synonimem najbardziej wymagającej literatury. $Z$ drugiej strony różne pokolenia hiszpańskich poetów znajdujące w poetyce Zagajewskiego wspólne elementy. Dla tych pokoleń Adam Zagajewski jest jakby ogniwem łączącym przeciwstawne sposoby rozumienia aktu poetyckiego w Hiszpanii i modelowym reprezentantem „polskiej szkoły poetyckiej”. Można powiedzieć, że Adam Zagajewski w świecie języka hiszpańskiego odgrywa w tym momencie rolę, jaką w Stanach Zjednoczonych odegrał Czesław Miłosz: staje się przedstawicielem zarówno tradycji literackiej, jak i pewnego sposobu rozumienia dyskursu poetyckiego. Jasność, codzienność, ironia (zdaniem niektórych hiszpańskich komentatorów: nieobecna w wierszach Zagajewskiego, zdaniem innych - stosowana subtelnie) i nawet broniony wysoki styl stanowią fortecę współczesnej poezji hiszpańskiej ${ }^{48}$.

43 Do tego stopnia, że jedna książka poetycka, Niewidzialna ręka, została wydana wcześniej po hiszpańsku niż po angielsku. Fakt, który może nasuwać pewne wnioski, zwłaszcza dotyczące pozycji autora na rynku.

44 A. Zagajewski, Deseo, tłum. X. Farré, Barcelona 2005.

45 Tenże, Antenas, tłum. X. Farré, Barcelona 2007.

46 Tenże, Mano invisible, tłum. X. Farré, Barcelona 2012.

47 Tenże, Asimetría, tłum. X. Farré, Barcelona 2017.

48 Kilka wypisów na temat rozpoznań hiszpańskich krytyków, dotyczących funkcjonowania ironii w poezji Zagajewskiego. Martín López-Vega w przedmowie do jedynej antologii wierszy Zagajewskiego w Hiszpanii pisze: „[Sa] wiersze, w których jest tło gorzkości i ironii” (M. López-Vega, Demasiadas elegias, demasiada memoria [w:] A. Zagajewski, Poemas escogidos, 
Poeci różnych pokoleń szukają w poetyce autora Asymetrii potwierdzenia nie tylko swoich postulatów estetycznych, ale także potwierdzenia przebywania bezpośrednio z twórczością „polskiej szkoły poezji”. Dzieła Adama Zagajewskiego znajdują się na rynku hiszpańskim obok książek poetyckich innych polskich poetów współczesnych, stwarzając specyficzny obraz polskiej szkoły poetyckiej. Mimo że uznaje się, że starsi autorzy (Miłosz, Herbert, Różewicz, Szymborska) stanowią trzon tej szkoły, Adam Zagajewski wyłania się nie tylko jako bezpośredni spadkobierca, ale nawet bardziej jako najważniejszy obecnie reprezentant tego trendu. Proces tłumaczenia jego dzieł podążał własnymi drogami, choć niewątpliwie wpływała nań znajomość polskich poetów poprzednich pokoleń, mimo że na język hiszpański poeci ci byli przekładani na mniejszą skalę, w niektórych przypadkach nawet później. W swoim słynnym tekście o miejscu literatury tłumaczonej w polisystemie literackim Itamar Even Zohar mówi o roli dzieł przekładanych:

Jakiego typu relacje mogłyby łączyć dzieła przekładane, które prezentuje się nam w charakterze faktów dokonanych, importowanych z obcej literatury, oderwanych od macierzystych kontekstów, a zatem zneutralizowanych z punktu widzenia zmagania między centrum a peryferiami?

Twierdzę, że utwory tłumaczone skorelowane są co najmniej pod dwoma względami:

1) pod względem wyboru tekstów źródłowych przez kulturę docelową, jako że zasady wyboru nigdy nie pozostają bez związku z kosystemami literatury docelowej (by ująć to w sposób możliwie oględny);

2) pod względem przyjmowanych przez nie szczególnych norm, zachowań i strategii (krótko mówiąc: pod względem wykorzystania repertuaru literackiego), które wynikają z ich relacji z innymi kosystemami tej kultury ${ }^{49}$.

Uwagi izraelskiego teoretyka można by odnieść do polskiej poezji współczesnej, przetłumaczonej na hiszpański. Do roli, którą odegrała i którą odgrywa twórczość poetycka Adama Zagajewskiego stosuje się zarówno pierwszy, jak

tłum. E. Bortkiewicz, Valencia 2005, s. 16). Natomiast krytyczka Mercedes Monmany zauważa: „Wstrzemięźliwy i skrupulatny styl pisania, niemal nieustannie przesycony łagodną i ironiczną melancholią" (M. Monmany, Adam Zagajewski: Bohaterowi zwyktości [w:] i cień i światto... both light and shadow... (Gtosy o twórczości Adama Zagajewskiego), red. A. Czabanowska-Wróbel, Kraków 2015). Poeta i krytyk Antonio Colinas (jeden z najbardziej uznanych poetów hiszpańskich z tego samego pokolenia co Adam Zagajewski, urodzony w 1946), podkreśla w recenzji Pragnienia, że u autora polskiego występuje ironia, choć sam autor dystansuje się od niej: „nie używa [Zagajewski - dop. X.F.] ironii w prosty sposób ani jako wygodnego elementu poetyckiego, jako kliszy. Nawet wydaje się, że właśnie poeta próbuje bronić się przed ironią i ciszą, dwiema strategiami, które ciążą nad poezją naszych czasów” (A. Colinas, Deseo, „El Cultural", 2.02.2006, https://elcultural.com/Deseo, dostęp: 19.03.2020).

49 I. Even-Zohar, Miejsce literatury ttumaczonej w polisystemie literackim, tłum. M. Heydel [w:] Wspótczesne teorie przektadu, red. P. Bukowski, M. Heydel, Kraków 2009, s. 197-198. 
i drugi punkt. Ta twórczość pozwala czytelnikowi hiszpańskiemu wyrobić sobie pogląd na polską poezję (w sposób okrojony i, co nieuniknione, częściowy, wyciszający inne tendencje polskiej poezji). Z drugiej strony sam hiszpański system poetycki asymiluje tę twórczość i wtapia ją w swój wewnętrzny proces transformacyjny, polegający na wzmacnianiu dyskursu klarownego, poezji figuratywnej i jasnej.

\section{Bibliografia}

Abril J.C., Deshabitados, Granada 2008.

Barba R.M., Última poesía española (1990-2005). Antología, Madrid 2006.

Berman A., Pour une critique des traductions: John Donne, Paris 1994.

Colinas A., Deseo, „El Cultural”, 2.02.2006, https://elcultural.com/Deseo, dostęp: 19.03.2020.

Darwish M., El lecho de una extraña, tłum. M.L. Prieto, Madrid 2005.

Darwish M., Menos rosas, tłum. M.L. Prieto, Madrid 2001.

Even-Zohar I., Miejsce literatury thumaczonej w polisystemie literackim, thum. M. Heydel [w:] Wspótczesne teorie przektadu, red. P. Bukowski, M. Heydel, Kraków 2009.

Doce J., Materialismo del creyente [w:] tenże, Zona de divagar, Madrid 2014.

García Martín J.L., La poesía figurativa. Crónica parcial de quince años de poesía española, Sevilla 1992.

García-Posada M., Poesía española. 10. La nueva poesía (1975-1992), Barcelona 1996.

Gil de Biedma J., El pie de la letra: Ensayos 1955-1979, Barcelona 1980.

Herbert Z., Informe desde la ciudad sitiada y otros poemas, tłum. X. Ballester, Madrid 1993.

Herbert Z., Poesía completa, tłum. X. Ballester, Barcelona 2012.

Heydel M., Gorliwość ttumacza. Przektad poetycki w twórczości Czestawa Mitosza, Kraków 2013.

Klejnocki J., Dziesięćpowodów, dla których inni poeci polscy nienawidza Adama Zagajewskiego [w:] i cień i światto... O twórczości Adama Zagajewskiego, red. A. Czabanowska-Wróbel, Kraków 2015.

Langbaum R., The Poetry of Experience. The Dramatic Monologue in Modern Literary Tradition, New York 1980 (1957).

Liebert J., Antología poética, tłum. A. Benítez Burraco, A. Sobieska, Madrid 2005. Lipska E., Fresas blancas, tłum. F. Presa Ginzález, Madrid 2001.

Lipska E., La astillal La naranja de Newton, tłum. A. Benítez Burraca, A. Sobieska, Gijón 2010.

López-Vega M., Demasiadas elegías, demasiada memoria [w:] A. Zagajewski, Poemas escogidos, tłum. E. Bortkiewicz, Valencia 2005. 
Miłosz C., A Book of Luminous Things: An International Anthology of Poetry, Orlando 1998.

Miłosz C., El pensamiento cautivo, tłum. E. Revol, Barcelona 1981.

Miłosz C., El valle del Issa, tłum. A. Rodón Klemensiewicz, Barcelona 1982.

Miłosz C., Otra Europa, tłum. A. Cousté, Barcelona 1981.

Miłosz C., Postwar Polish Poetry, wyd. 3 rozszerz., Berkeley-Los Angeles 1983.

Miłosz C., Świadectwo poezji. Sześć wyktadów o dotkliwościach naszego wieku, Warszawa 1990 (1983).

Miłosz C., Tierra inalcanzable. Antología poética, tłum. X. Farré, Barcelona 2011.

Miłosz C., The Witness of Poetry, Cambridge 1994 (1983).

Miłosz C., Życie na wyspach, Kraków 1997.

Monmany M., Adam Zagajewski: Bohaterowi zwyktości [w:] i cień i światto... both light and shadow... (Gtosy o twórczości Adama Zagajewskiego), red. A. Czabanowska-Wróbel, Kraków 2015.

Murcia A., Beltrán G., Farré X., Poesía a contragolpe, Zaragoza 2012.

Nolens L., Puertas entreabiertas, 1 y 2, tłum. S. van den Bremt, Madrid 2013.

Nooteboom C., Luz por todas partes (Antología), tłum. F.G. de la Banda, Madrid 2013.

Nordbrandt H., Nuestro amor es como Bizancio, tłum. F. Uriz, Barcelona 2003.

Popa V., El cansancio ajeno (Poesía completa), tłum. D. Sužnjević, Madrid 2012.

Różewicz T., Poesía abierta, tłum. F. Presa González, Barcelona 2003.

Villena L.A. de, Postnovísimos, Madrid 1986.

Walcott D., Mapa Nowego Świata. Wiersze wybrane, wybór, red. M. Heydel, tłum. S. Barańczak i in., Kraków 2008.

Zagajewski A., Antenas, tłum. X. Farré, Barcelona 2007.

Zagajewski A., Asimetría, tłum. X. Farré, Barcelona 2017.

Zagajewski A., Deseo, tłum. X. Farré, Barcelona 2005

Zagajewski A., En la belleza ajena, tłum. Á.E. Díaz-Pintado Hilario, Valencia 2004.

Zagajewski A., Mano invisible, tłum. X. Farré, Barcelona 2012.

Zagajewski A., Tierra del fuego, tłum. X. Farré, Barcelona 2004.

Zagajewski A., Uwagi o wysokim stylu [w:] tegoż, Obrona żarliwości, Kraków 2002. 